Atthough airway inflammation and airway hyperreactivity are observed after allergen inhalation both in allergic humans and animals, little is known about the mechanisms by which inflammatory cells can contribute to allergen-induced airway hyperreactivity. To understand how inflammatory cell infiltration can contribute to airway hyperreactivity, the location of these cells within the airways may be crucial.

Using a guinea pig model of acute allergic asthma, we investigated the inflammatory cell infiltration in different airway compartments at 6 and $24 \mathrm{~h}$ (i.e. after the early and the late asthmatic reaction, respectively) after allergen or saline challenge in relation to changes in airway reactivity (AR) to histamine.

At $6 \mathrm{~h}$ after allergen challenge, a threefold $(p<0.01)$ increase in the AR to histamine was observed. At $24 \mathrm{~h}$ after challenge, the AR to histamine was lower, but still significantly enhanced (1.6-fold, $p<0.05$ ).

Adventitial eosinophil and neutrophil numbers in both bronchi and bronchioli were significantly increased at $6 \mathrm{~h}$ post-allergen provocation as compared with saline $(p<0.01$ for all), while there was a strong tendency to enhanced eosinophils in the bronchial submucosa at this time point $(p=0.08)$. At $24 \mathrm{~h}$ after allergen challenge, the eosinophilic and neutrophilic cell infiltration was reduced. $\mathrm{CD}^{+} \mathrm{T}$ lymphocytes were increased in the adventitial compartment of the large airways $(p<0.05)$ and in the parenchyma $(p<0.05)$ at $24 \mathrm{~h}$ post-allergen, while numbers of $\mathrm{CD8}^{+}$cells did not differ from saline treatment at any time point post-provocation.

The results indicate that, after allergen provocation, inflammatory cell numbers in the airways are mainly elevated in the adventitial compartment. The adventitial inflammation could be important for the development of allergen-induced airway hyperreactivity.

Key words: Eosinophils, Neutrophils, Lymphocytes, Submucosa, Adventitia, Parenchyma, Allergen-challenge, Airway hyperreactivity, Guinea pigs

\section{Inflammatory cell distribution in guinea pig airways and its relationship to airway reactivity}

\author{
Fiona Westerhof ${ }^{1, C A}$, Wim Timens ${ }^{2}$, \\ Annemiek van Oosten², Annet B. Zuidhof', \\ Nathalie Nauta ${ }^{2}$, Martin Schuiling ${ }^{1}$, \\ Johannes T. W. M. Vos ${ }^{2}$, Johan Zaagsma ${ }^{1}$, \\ Herman Meurs ${ }^{1}$ and Wilko Coers ${ }^{2}$
}

${ }^{1}$ Department of Molecular Pharmacology, University Centre for Pharmacy, A. Deusinglaan 1, 9713 AV Groningen, the Netherlands; ${ }^{2}$ Department of Pathology and Laboratory Medicine, University Hospital Groningen, Hanzeplein 1, 9713 GZ Groningen, the Netherlands

\author{
${ }^{\mathrm{CA}}$ Corresponding Author \\ Tel: (+)31 503633304 \\ Fax: (+)31 503636908 \\ E-mail: FJ.Westerhof@farm.rug.nl
}

\section{Introduction}

Allergic asthma in man is clinically characterized by bronchoconstriction in response to inhaled aeroallergens, resulting in an early asthmatic reaction (EAR) that is often followed by a late asthmatic reaction (LAR). The EAR is thought to be primarily caused by an immunoglobulin (Ig)E-mediated release of mast cell mediators, while the LAR is associated with the recruitment and activation of inflammatory cells in the lung, including eosinophils, neutrophils and lymphocytes. ${ }^{1-4}$

Another important feature of allergic asthma is the development of increased reactivity of the airways to non-specific stimuli following allergen exposure, referred to as airway hyperreactivity (AHR). Allergen- induced AHR has been observed in patients with a dual asthmatic reaction, and may already be present before the onset of the LAR. ${ }^{5-8}$ It is generally thought that inflammatory cell influx in the airways is involved in the development of AHR. However, a close relationship between the number of inflammatory cells in the airway lumen or mucosa and chronic AHR has not invariably been found, which may possibly be due to airway remodeling after prolonged inflammation. $^{9-11}$

Although information from biopsy studies is available about inflammation in the airway wall of asthmatics, little is known about the distribution of inflammatory cells throughout the entire airway circumference and lung tissue of these patients. Detailed knowledge about this distribution may be 
pivotal to understanding the role of inflammatory cells in the development of AHR. Techniques to assess airway inflammatory cell distribution in relation to AHR in asthmatic patients are limited: biopsy samples can only be collected from superficial layers of larger proximal airways, which provide no information about deeper peribronchial areas nor about more distal smaller airways. In addition, cells obtained from bronchoalveolar lavage (BAL) and sputum induction represent primarily luminal inflammation. Detailed histopathologic studies of the airways from patients with fatal and non-fatal asthma with respect to inflammatory cell distribution within and along the airways have been performed, ${ }^{12-17}$ but cannot be quantitatively related with AHR.

The aim of the present study was to investigate the distribution of the inflammatory infiltrate both within the airway wall (i.e. the adventitia and submucosa) and between the central and peripheral airways and the parenchyma in relation to AHR after the allergeninduced EAR and LAR. To this purpose, we used a guinea pig model of allergic asthma with great qualitative and quantitative similarities in allergeninduced EAR, LAR and AHR after both reactions, and airway inflammation as assessed by BAL compared with asthmatic patients. ${ }^{18}$

\section{Materials and methods}

\section{Animals}

Specified pathogen-free tri-colored bastard male guinea pigs (Charles River; SAVO, Kiszlegg, Germany) weighing 400-500 g were actively sensitized to ovalbumin as described previously. ${ }^{19}$ To obtain a shift to IgE class antibodies, an allergen solution containing $100 \mu \mathrm{g}$ of ovalbumin and $100 \mathrm{mg}$ of $\mathrm{Al}(\mathrm{OH})_{3}$ per $\mathrm{ml}$ saline was used. The allergen solution was gently rotated for $60 \mathrm{~min}$ to obtain an alu-gel, and $0.5 \mathrm{ml}$ was injected intraperitoneally, while another $0.5 \mathrm{ml}$ was divided over seven intracutaneous injection sites in the proximity of lymph nodes in the paws, lumbar regions and neck. Animals were operated on 3 weeks after sensitization and used experimentally $4-8$ weeks after sensitization. The animals were housed in individual cages in climate-controlled animal quarters, and were given water and food ad libitum. All protocols described were approved by the University of Groningen Animal Ethical Committee.

\section{Measurement of airway function}

Airway function was assessed by measuring pleural pressure $\left(P_{\mathrm{pl}}\right)$ as described previously. ${ }^{20}$ In short, a small saline-filled latex balloon connected to a salinefilled canula was surgically implanted in the thoracic cavity. The free end of the canula was subcutaneously driven to the neck of the guinea pigs, where it was exposed and attached permanently. The canula was connected to a pressure transducer (Ohmeda DTX ${ }^{\mathrm{TM}}$; SpectraMed, Bilthoven, The Netherlands) using an external saline-filled canula. $P_{\mathrm{p} 1}\left(\mathrm{cmH}_{2} \mathrm{O}\right)$ was measured continuously using an on-line computer system. We have previously shown that changes in $P_{\mathrm{pl}}$ are linearly correlated to changes in airway resistance and hence can be used as a sensitive index for allergic and non-allergic bronchoconstriction. ${ }^{20}$ In this way, airway function can be monitored repeatedly and continuously for prolonged periods of time, while the animals are unaware of the measurements being taken.

\section{Provocation procedures}

Ovalbumin and histamine provocations were performed by inhalation of aerosolized solutions, produced by a DeVilbiss nebulizer (type 646; DeVilbiss, Somerset, PA, USA), with an airflow of $81 / \mathrm{min}$ resulting in an output of $0.33 \mathrm{ml} / \mathrm{min}$. Provocations were carried out in a specially designed perspex cage (internal volume, 91) in which the guinea pigs could move freely.

Before the start of the experiment, the animals were habituated to the experimental conditions and the provocation procedures on two sequential days at least 1 week after surgery, when preoperative weight was restored. On the first day, the animals were placed in the provocation cage unconnected to the pressure transducer. After an adaptation period of at least $30 \mathrm{~min}$, three consecutive provocations with saline were performed, each provocation lasting $3 \mathrm{~min}$ and separated by a $7 \mathrm{~min}$ interval. The next day, this procedure was repeated with the animals connected to the measurement system

During the experimental protocol following the habituation procedure, all provocations were preceded by a $30 \mathrm{~min}$ adaptation period and followed by two consecutive control provocations with saline ( $3 \mathrm{~min}$ ) as already described. A baseline $P_{\mathrm{p} 1}$ value was calculated by averaging the $P_{\mathrm{pl}}$ values from the last $20 \mathrm{~min}$ of the adaptation period.

To assess the airway reactivity for histamine, histamine provocations were started with a solution containing $25 \mu \mathrm{g} / \mathrm{ml}$ of histamine in saline, followed by increasing dosage steps of $25 \mu \mathrm{g} / \mathrm{ml}$. Histamine provocations lasted $3 \mathrm{~min}$, separated by $7 \mathrm{~min}$ intervals. Animals were challenged until $P_{\mathrm{pl}}$ was increased by more than $100 \%$ above baseline, for at least three consecutive minutes. $P_{\mathrm{pl}}$ returned to baseline value within $15 \mathrm{~min}$ after the last histamine provocation. The airway reactivity (AR) to histamine was expressed as the concentration causing a $100 \%$ increase in $P_{\mathrm{p} 1}$ $\left(\mathrm{PC}_{100}\right)$, which was calculated by linear intrapolation of the concentration- $P_{\mathrm{pl}}$ response curve. Changes in AR towards histamine were expressed as the ratio $\mathrm{PC}_{100} \mathrm{pre} / \mathrm{post}$ allergen challenge. 
Ovalbumin provocations were performed by inhalation of increasing concentrations of 1.0, 3.0 and $5.0 \mathrm{mg} / \mathrm{ml}$ of ovalbumin in saline for $3 \mathrm{~min}$ each, separated by $7 \mathrm{~min}$ intervals. Allergen inhalations were discontinued when an increase in $P_{\mathrm{p} 1}$ of $100 \%$ or more was observed. Using these conditions, none of the animals developed anaphylactic shock after allergen provocation. For the quantitative assessment of the EAR and LAR, airway function was continuously measured up to $24 \mathrm{~h}$ after allergen challenge. The magnitudes of the allergen-induced EAR and LAR were expressed as the area under the $P_{\mathrm{pl}}$ timeresponse curve (AUC) between 0 and $6 \mathrm{~h}$ after allergen provocation for the EAR, and between 8 and $24 \mathrm{~h}$ after provocation for the LAR. $P_{\mathrm{pl}}$ was expressed as the percentage change from baseline, and AUC was calculated by trapezoid integration over discrete ( $5 \mathrm{~min}$ ) time periods. Based on saline control provocations, threshold values of AUC (mean + 2 SD; 99\% confidence interval) were defined as $1185 \% \times 5 \mathrm{~min}$ for a positive early response and $2790 \% \times 5$ min for a positive late response, respectively. ${ }^{18}$

Histamine $\mathrm{PC}_{100}$ values were assessed $24 \mathrm{~h}$ before, and $6 \mathrm{~h}$ (after the EAR) and $24 \mathrm{~h}$ (after the LAR) after ovalbumin provocation. Inhalations with saline instead of ovalbumin served as controls. For tissue sampling, animals were terminated at $6.5 \mathrm{~h}$ (group 1) or at $24.5 \mathrm{~h}$ (group 2) after ovalbumin or saline provocation.

\section{Tissue processing}

Guinea pigs were killed by cervical dislocation, after which the lungs were immediately resected and kept on ice in a petri dish during further processing. Additionally, the spleen was removed for qualitative assessment of antibody specificity. The superior and median lobes of the right lung and the spleen were snap frozen at $-80^{\circ} \mathrm{C}$ in isopentane, and tissue was stored at $-80^{\circ} \mathrm{C}$. Frozen sections were cut at a thickness of $4 \mu \mathrm{m}$ and stored, wrapped in aluminium foil, at $-20^{\circ} \mathrm{C}$ until use (within 2 weeks).

\section{Inflammatory cell characterization}

Inflammatory cells were identified using histochemical and immunohistological techniques. Eosinophils were identified using hematoxylin-eosin staining. Neutrophils were identified by a combination of morphologic criteria and tissue non-specific alkaline phosphatase enzyme histochemistry, as described previously. $^{21}$

Infiltration of $\mathrm{T}$ cells in the lung was analyzed by immunohistological techniques using a rabbit antihuman CD3 polyclonal antibody (Dakopatts Ltd, High Wycombe, UK) as a pan T-cell antibody, and the murine monoclonal CT6 as a $\mathrm{CD}^{+}{ }^{+}$T-cell antibody ${ }^{22}$ (generously provided by Prof. R.J. Scheper, Free University of Amsterdam). In brief, frozen sections were fixed at room temperature (RT) for $10 \mathrm{~min}$ in $100 \%$ acetone and washed for $5 \mathrm{~min}$ in phosphatebuffered saline (PBS) ( $\mathrm{pH}$ 7.4). To prevent nonspecific staining, the slides were incubated for $30 \mathrm{~min}$ with $10 \%$ normal goat or normal rabbit serum, respectively, diluted in PBS. Then, the sections were incubated for $1 \mathrm{~h}$ at RT with the primary antibody diluted (1:100 and 1:5000, respectively) in 1\% bovine serum albumin in PBS. After rinsing three times with PBS for $5 \mathrm{~min}$, endogenous peroxidase activity was blocked by incubating the slides in $0.075 \%$ hydrogen peroxide in PBS for $30 \mathrm{~min}$. Following three washes with PBS, the slides were incubated for $30 \mathrm{~min}$ with peroxidase-conjugated secondary antibodies (Dakopatts, Glosstrup, Denmark), diluted in $2 \%$ normal guinea pig serum in PBS. A peroxidase-conjugated goat-anti-rabbit IgG antibody (dilution 1:100) was used for the detection of the CD3 polyclonal antibodies, and a peroxidase-conjugated rabbit-antimouse IgG (dilution 1:50) was used for the detection of the CT6 monoclonal antibodies. Next, the sections were washed in PBS and the peroxidase activity was developed in a freshly prepared solution of 3-amino9-ethylcarbazol, containing $0.03 \%$ hydrogen peroxide for $10 \mathrm{~min}$. Counterstaining was performed using Mayer's hematoxylin. Antibody specificity was checked by incubating adjacent lung sections with non-relevant antibodies. Guinea pig spleen tissue served as a positive control for specificity.

\section{Cell quantification analysis}

Using a light microscope (Olympus BH-2, Paes, Zoeterwoude, The Netherlands), positively stained cells were enumerated in three anatomical areas as indicated in Fig. 1. The numbers of eosinophils, neutrophils, total $\mathrm{T}$ cells and $\mathrm{CD8}^{+} \mathrm{T}$ cells were counted employing an eyepiece graticule comprising 100 squares of known area. The number of positive cells present in the submucosa was expressed as cells per millimeter of basement membrane. The length of the basement membrane was estimated using the formula derived from Buffons needle problem: $B_{\mathrm{a}}=$ $\left[(\pi / 2) / I_{\mathrm{L}}\right] * d,{ }^{23}$ where $B_{\mathrm{a}}$ is the length of the boundary $(\mathrm{mm}), I_{\mathrm{L}}$ is the number of intersections formed by the boundary with the parallel lines of the grid, and $d$ is the distance between two parallel grid lines ( $\mathrm{mm}$ ).

Adventitial cell counts were carried out in the same airways. Positive cells were expressed as cells per millimeter of external smooth muscle perimeter. This perimeter was also estimated using Buffons formula. In the large airways, the adventitia was defined as the area between the smooth muscle and the cartilage; in the small airways, the adventitia was defined as a $50 \mu \mathrm{m}$ border outside and directly adjacent to the smooth muscle. In the parenchyma, positively stained 


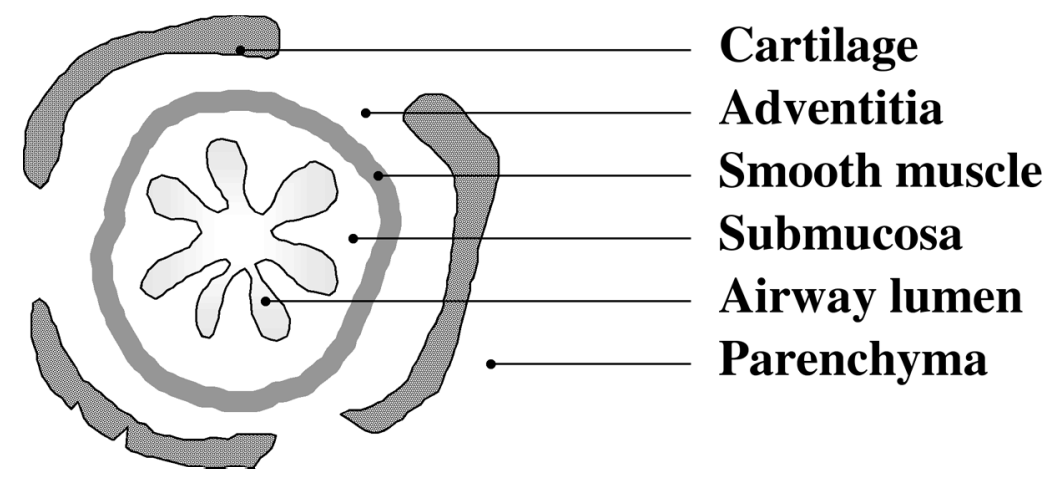

FIG. 1. Anatomical areas studied in counting cellular infiltrates. In the parenchyma, random fields were counted, well away from the airway. Adventitia, area between the smooth muscle layer and cartilage, or in the absence of cartilage, in a $50 \mu \mathrm{m}$ layer adjacent to the outer edge of the smooth muscle; submucosa, area between the basement membrane and the inner perimeter of the smooth muscle layer.

cells were expressed as percent of total cell counts. Per specimen, at least three large and three small airways were enumerated and, in the parenchyma, four random fields of $6.25 \times 10^{4} \mu \mathrm{m}^{2}$ (the total area of the graticule) were counted, and average values were calculated per animal.

\section{Statistical analysis}

Statistical analysis on the magnitudes of the early and the late asthmatic responses, and on the cell counts between treatment groups, was performed using the unpaired Mann-Whitney rank sum test. $\mathrm{PC}_{100}$ values before and after allergen challenge were compared using a one-way analysis of variance. When significance was observed $(p<0.05)$, a complementary Student-Newman-Keuls test was performed. For comparison of AHR at different time points within treatment groups, a Wilcoxon signed-rank test was used.

For the correlation between AHR and inflammatory cells, correlation coefficients and $p$ values were calculated using Spearman rank order correlation analysis.

\section{Results}

\section{Ovalbumin-induced early and late asthmatic} reactions

Figure 2 shows a typical example of a dual asthmatic reaction, induced by ovalbumin provocation. The EAR starts with a sharp increase in $P_{\mathrm{pl}}$, which is maximal within $20 \mathrm{~min}$ and lasts $2-4 \mathrm{~h}$. The LAR starts at approximately $8 \mathrm{~h}$ after allergen provocation, being reversible within $24 \mathrm{~h}$ after the challenge. The airway responses to allergen and saline control provocations in animals terminated after the EAR and the LAR are presented in Table 1.

\section{Airway reactivity}

Table 2 shows that an approximately threefold $(p<$ 0.01 ) increase in AR to histamine was observed at $6 \mathrm{~h}$ after allergen provocation in both groups of animals, while a smaller but still significant AHR (1.57-fold increase, $p<0.05$ ) was observed at $24 \mathrm{~h}$ after allergen challenge in the animals terminated after the LAR. No change in airway reactivity was observed in salinechallenged control animals.

Distribution of inflammatory cells in ovalbumin and saline challenged animals

- Eosinophils. At $6 \mathrm{~h}$ after allergen provocation, a significant fourfold increase in eosinophils was observed in the adventitial layer of the bronchi $(p$ $<0.01$; Fig. 3A), whereas in the adventitial layer of the bronchioli an eightfold increase in eosinophil numbers was observed at the same time point $(p<0.01$; Fig. 3C). The adventitial eosinophil numbers were not significantly different between large and small airways. Twenty-four hours after allergen challenge, adventitial eosinophil numbers still tended to be elevated but no longer reached statistical significance. In the submucosal layer of the bronchi, eosinophils tended to be enhanced at $6 \mathrm{~h}$ after allergen exposure compared with saline ( $p=0.08$; Fig. 3B), while at $24 \mathrm{~h}$ post-allergen submucosal eosinophil numbers did not differ from controls. In addition, no significant change was observed in the eosinophil number of the bronchiolar submucosa (Fig. 3D). Furthermore, in the parenchyma, no changes in eosinophil numbers were observed either at 6 or $24 \mathrm{~h}$ after allergen (Fig. 3E). Cell numbers in saline treated groups did not differ from one another at any time point.

- Neutrophils. At $6 \mathrm{~h}$ after ovalbumin provocation, neutrophil numbers were significantly elevated in the adventitia of the bronchi $(p<0.01$; Fig. $4 \mathrm{~A})$ as 


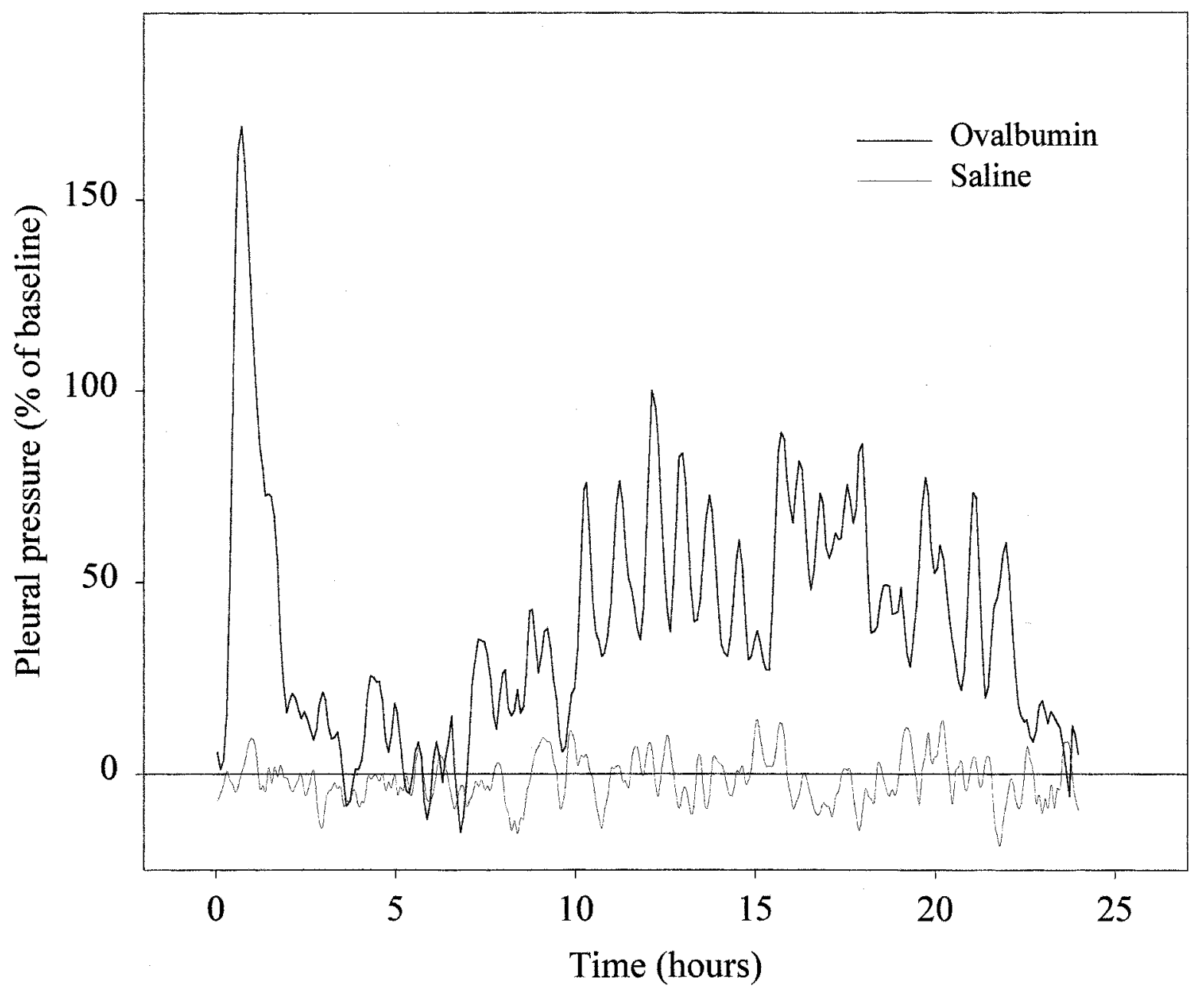

FIG. 2. Representative example of a dual asthmatic response after allergen provocation of an ovalbumin-sensitized guinea pig (thick line). The thin line represents the result of a saline control challenge. Provocations were performed at $0 \mathrm{~h}$.

well as in the bronchioli $(p<0.01$; Fig. 4C). Twentyfour hours after allergen exposure, some neutrophils were still present in the adventitia of the large airways, but these numbers were not significantly different from the saline-treated group (Fig. 4A). Few neutrophils were observed in the submucosal compartment of both large and small airways, after allergen provocation (Fig. 4B,D, respectively); however, no significant differences were observed compared with saline. No neutrophils were present in the submucosal compartment at any time point post-saline. Figure 4E shows that neutrophil numbers were not significantly elevated in the parenchyma at any time point post-

Table 1. Airway responses of sensitized guinea pigs after saline inhalation or ovalbumin provocation

\begin{tabular}{|c|c|c|c|c|c|}
\hline \multirow[t]{2}{*}{ Group } & \multirow[t]{2}{*}{ Inhalation } & \multicolumn{4}{|c|}{$\mathrm{AUC}(\% \times 5 \mathrm{~min})$} \\
\hline & & EAR & $(n)$ & LAR & $(n)$ \\
\hline 1 & $\begin{array}{l}\text { Saline } \\
\text { Ovalbumin }\end{array}$ & $\begin{array}{c}47 \pm 203 \\
3553 \pm 1156^{*}\end{array}$ & $\begin{array}{l}(6) \\
(6)\end{array}$ & $\begin{array}{l}- \\
-\end{array}$ & \\
\hline 2 & $\begin{array}{l}\text { Saline } \\
\text { Ovalbumin }\end{array}$ & $\begin{array}{c}135 \pm 862 \\
3071 \pm 317 \dagger\end{array}$ & $\begin{array}{l}(4) \\
(6)\end{array}$ & $\begin{aligned} 420 & \pm 873 \\
9038 & \pm 2545^{*}\end{aligned}$ & $\begin{array}{l}(4) \\
(4)\end{array}$ \\
\hline
\end{tabular}

Data are presented as area under the percent change in $P_{\mathrm{p} /}$ time-response curve (AUC) between 0 and $6 \mathrm{~h}$ after the allergen provocation for the early asthmatic reaction (EAR) and between $8 \mathrm{~h}$ and $24 \mathrm{~h}$ after allergen provocation for the late asthmatic reaction (LAR). Results represent mean values \pm SEM of $(n)$ animals. Group 1, guinea pigs terminated after the EAR; group 2, guinea pigs terminated after the LAR.

${ }^{*} p<0.05, \dagger p<0.01$ compared with saline inhalation, Mann-Whitney rank sum test. 
Table 2. Airway reactivity to inhaled histamine of sensitized guinea pigs at 6 and $24 \mathrm{~h}$ after saline or ovalbumin inhalation

\begin{tabular}{|c|c|c|c|c|c|}
\hline \multirow[t]{2}{*}{ Group } & \multirow[t]{2}{*}{ Inhalation } & \multicolumn{4}{|c|}{ Histamine $\mathrm{PC}_{100}$ pre/post inhalation } \\
\hline & & $6 \mathrm{~h}$ & $(n)$ & $24 \mathrm{~h}$ & $(n)$ \\
\hline 1 & $\begin{array}{l}\text { Saline } \\
\text { Ovalbumin }\end{array}$ & $\begin{array}{l}1.00 \pm 0.03 \\
2.97 \pm 0.34 \dagger\end{array}$ & $\begin{array}{l}(6) \\
(6)\end{array}$ & $\begin{array}{l}- \\
-\end{array}$ & \\
\hline 2 & $\begin{array}{l}\text { Saline } \\
\text { Ovalbumin }\end{array}$ & $\begin{array}{l}0.95 \pm 0.06 \\
3.22 \pm 0.51 \dagger\end{array}$ & $\begin{array}{l}(4) \\
(6)\end{array}$ & $\begin{array}{l}1.00 \pm 0.09 \\
1.57 \pm 0.34^{*} \neq\end{array}$ & $\begin{array}{l}(4) \\
(6)\end{array}$ \\
\hline
\end{tabular}

Airway reactivity is expressed as the ratio of histamine provocation concentration causing $100 \%$ increase in pleural pressure $\left(\mathrm{PC}_{100}\right)$ values obtained at $24 \mathrm{~h}$ before, and 6 and $24 \mathrm{~h}$ after inhalation of saline or ovalbumin. Data represent mean values \pm SEM of $(n)$ animals. Group 1 , guinea pigs terminated after the early asthmatic reaction; group 2, guinea pigs terminated after the late asthmatic reaction.

${ }^{*} p<0.05, \dagger p<0.01$ compared with before treatment, one-way analysis of variance followed by the Student-Newman-Keuls test; $¥ p<0.05$ compared with $6 \mathrm{~h}$ post-ovalbumin, Wilcoxon signed rank test.

allergen provocation as compared with salinetreated animals.

- T-lymphocytes. $\mathrm{CD}^{+}$T-cell numbers showed no quantitative changes at $6 \mathrm{~h}$ after allergen provocation in any of the compartments investigated in the allergen-treated group as compared with controls (Fig. 5A-E). At $24 \mathrm{~h}$, however, $\mathrm{CD}^{+}$cells were increased in both the adventitial layer of the large airways $(p<0.05)$ and in the parenchyma $(p<$ $0.05)$, as is shown in Fig. $5 \mathrm{~A}, \mathrm{E}$, respectively. $\mathrm{CD}^{+} \mathrm{T}$ cells showed no significant change at any time point, after either ovalbumin or saline treatment (not shown).

For all cell numbers, no significant differences between large and small airways were observed.

No significant correlations between allergeninduced cell infiltration in the different compartments and AHR were observed, except for $\mathrm{CD}^{+}$cells in the parenchyma at $24 \mathrm{~h}$ after ovalbumin $(r=0.89, p<$ $0.05)$.

\section{Discussion}

In a guinea pig model of allergic asthma, characterized by allergen-induced EAR, LAR and AHR after both reactions, we have explored the infiltration of eosinophils, neutrophils, and $\mathrm{T}$ lymphocytes in the submucosal and adventitial compartments of large (cartilaginous) and small (non-cartilaginous) airways at 6 and $24 \mathrm{~h}$ after allergen challenge. At $6 \mathrm{~h}$ after challenge (i.e. after the EAR, but before the initiation of the LAR; Fig. 2), a significant increase in eosinophil and neutrophil numbers was observed in the adventitia of both large and small airways, while there was a tendency to an increased eosinophil number in the bronchial submucosa at this time point. The infiltration of eosinophils and neutrophils was reduced at $24 \mathrm{~h}$ after challenge, whereas a significant T-cell infiltration was observed at this time point both in the bronchial adventitia and in the parenchyma. The allergen-induced increase in inflammatory cells was associated with the development of AHR to histamine, which, as shown previously in this model, ${ }^{18}$ was maximal at $6 \mathrm{~h}$ after challenge and decreased, but still significantly present, at $24 \mathrm{~h}$ after the provocation. The temporal association between the degree of, mainly adventitial, infiltration of eosinophils and neutrophils and the degree of AHR to histamine at 6 and at $24 \mathrm{~h}$ after allergen challenge may indicate a causal relationship between these events. However, no significant correlations between infiltration of these cells in any of the airway compartments and AHR were observed. In addition, the enhanced T-cell infiltration at $24 \mathrm{~h}$ after allergen challenge was not significantly correlated with AHR. Apart from the relatively low number of experiments, this may indicate that other factors may be involved in the development of allergen-induced AHR.

Likewise, in human asthmatics, no or only weak correlations were found between AHR and inflammatory cell numbers in $\mathrm{BAL},{ }^{9,24-27}$ induced sputum,,$^{9,28-31}$ and bronchial biopsies. ${ }^{9,32-37}$ However, inflammatory cells found in BAL or sputum represent luminal instead of tissue inflammation, while endobronchial biopsies only provide information about the inflammatory response close to the surface of the proximal airways (mucosa and submucosa), so a possible relationship between AHR and inflammatory cells in the airways could be easily overlooked using these techniques.

Indeed, in previous studies using our guinea pig model of allergic asthma, no significant correlation was found between eosinophil and neutrophil numbers in BAL and AHR at 6 and $24 \mathrm{~h}$ after allergen provocation. ${ }^{18}$ In this model of acute allergic asthma, it was found that BAL eosinophils and neutrophils were increased at $6 \mathrm{~h}$ after allergen provocation, and even further increased at $24 \mathrm{~h}$ after allergen. In the current study, it was observed that tissue eosinophils and neutrophils peak at $6 \mathrm{~h}$ post-allergen and are reduced at $24 \mathrm{~h}$, supporting the idea that these cells migrate from the tissue to the lumen. A similar relationship between the time course of tissue and 


\section{Eosinophils}
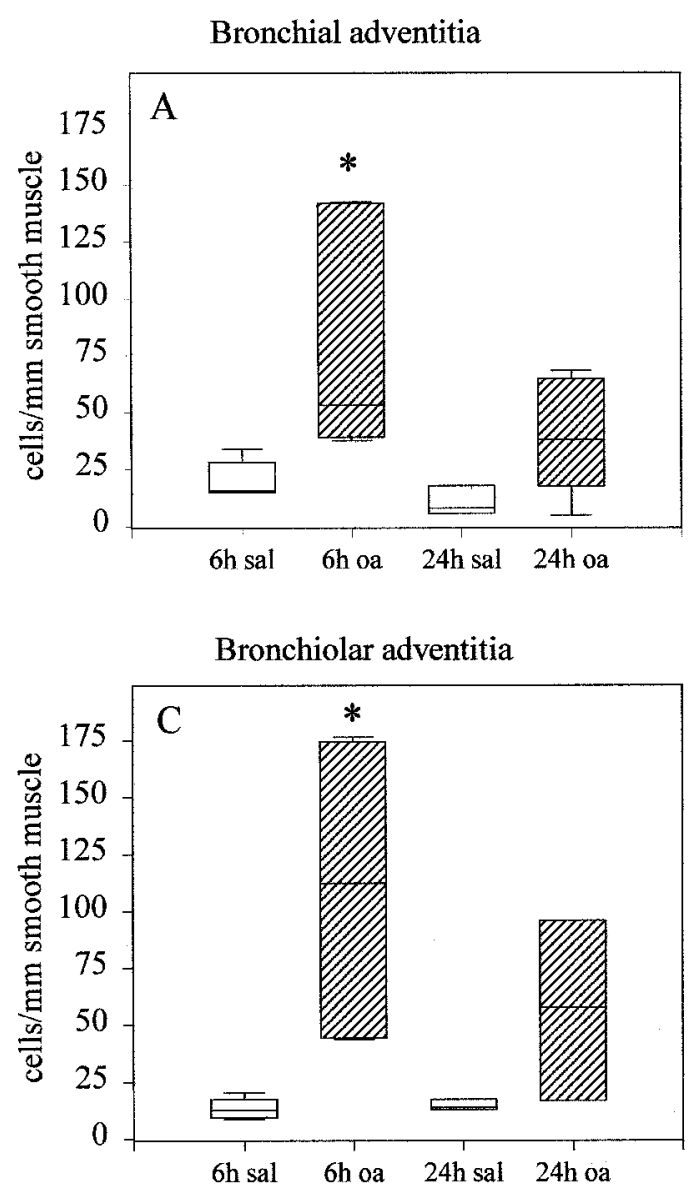

Parenchyma

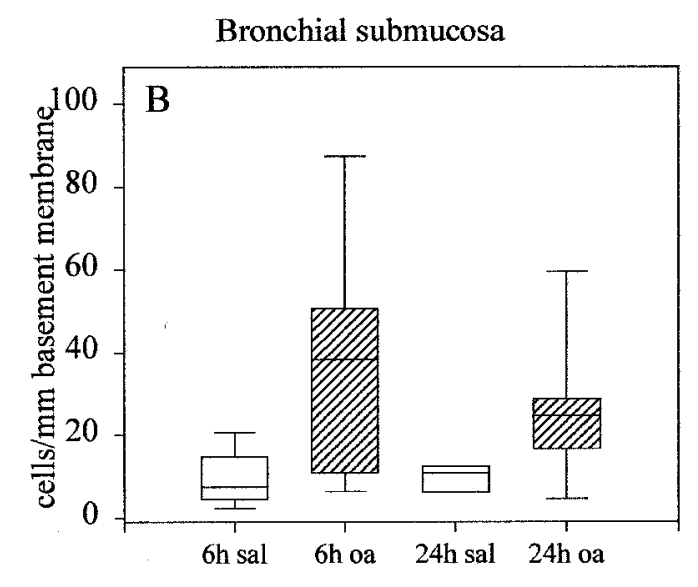

Bronchiolar submucosa

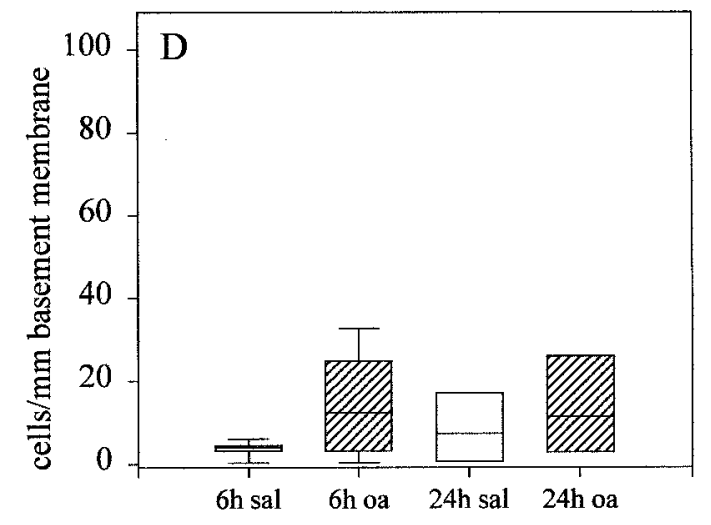

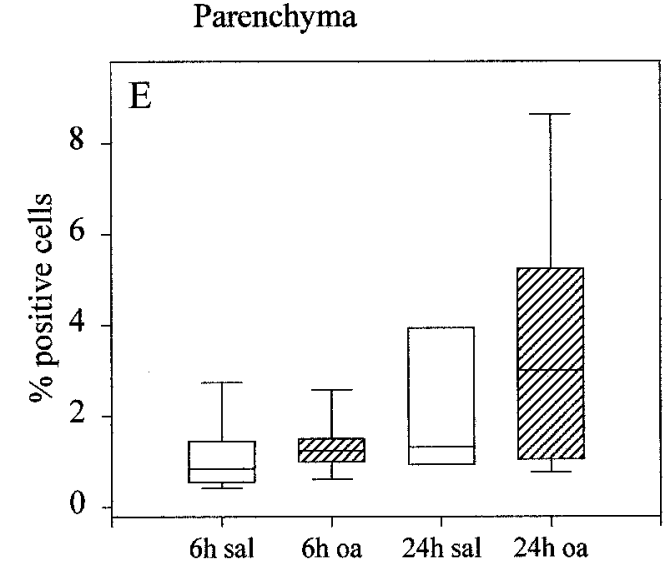

FIG. 3. Eosinophil numbers at 6 and $24 \mathrm{~h}$ after saline control inhalation (sal, open bars) or ovalbumin inhalation (oa, hatched bars) in different airway compartments. Data represent median values, interquartiles, and 10th and 90th percentiles of four to six animals. Statistical analysis: ${ }^{*} p<0.01$, Mann-Whitney rank sum test.

luminal infiltration of eosinophils was also found in another guinea pig study ${ }^{38}$ and in asthmatic patients. ${ }^{39}$

In addition to cellular infiltration in the different airway compartments, the activation state of the infiltrated cells may be an important determinant of allergen-induced AHR. Thus, in biopsy studies in patients, a positive correlation was found between (activated) EG2 ${ }^{+}$eosinophils and AHR. ${ }^{34}$ In addition, in mild asthmatics, a significant correlation was found between the AHR to histamine and the concentration of major basic protein (MBP) in the BAL. ${ }^{25}$ Accordingly, in our guinea pig model, a possible relationship between eosinophil activation and AHR was indicated 


\section{Neutrophils}

Bronchial adventitia
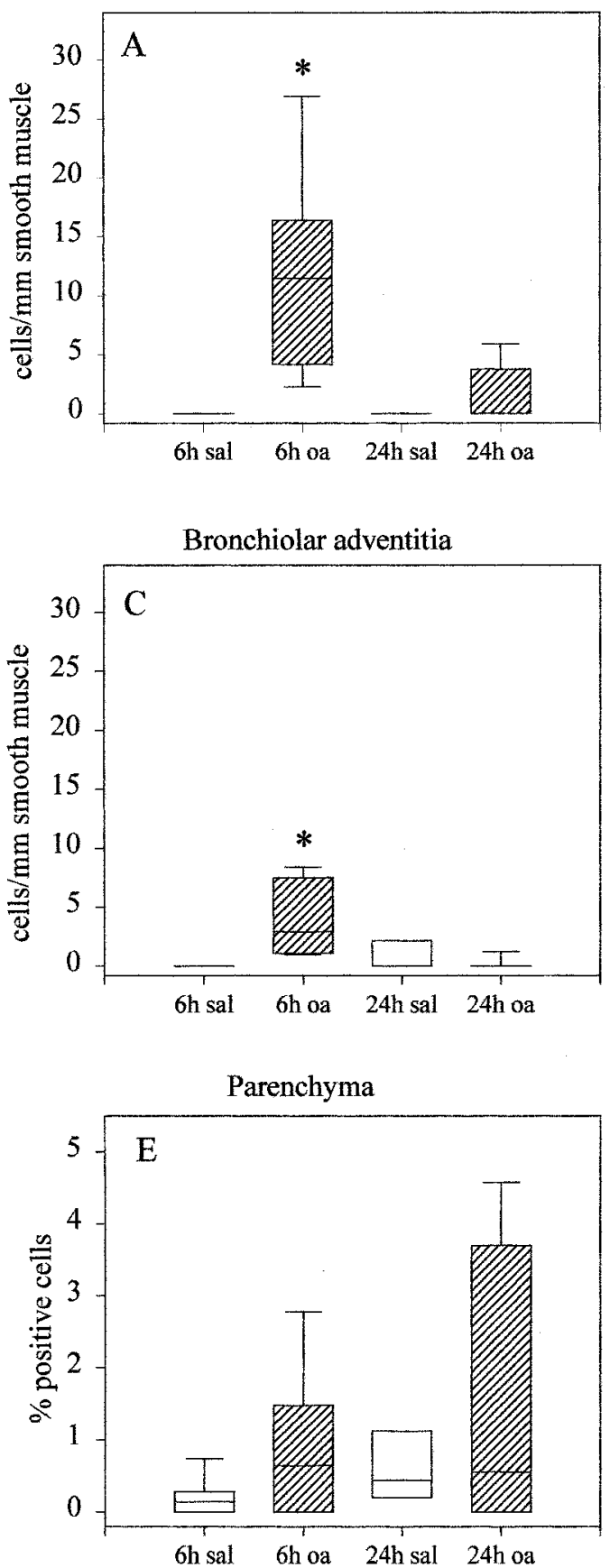

Bronchial submucosa

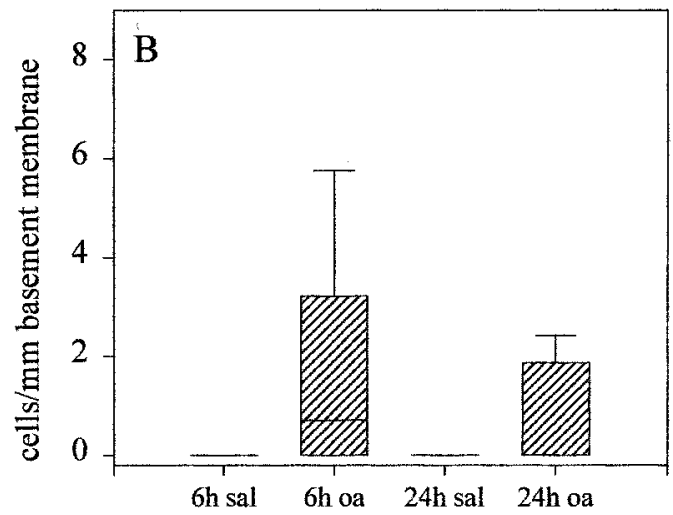

Bronchiolar submucosa

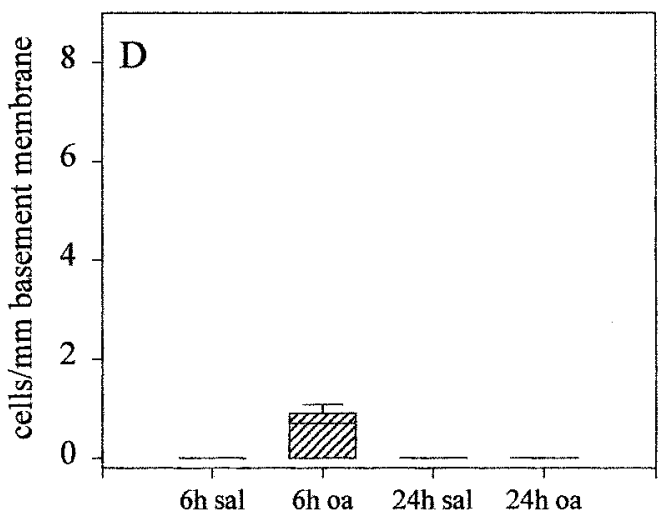

FIG. 4. Neutrophil numbers at 6 and $24 \mathrm{~h}$ after saline control inhalation (sal, open bars) or ovalbumin inhalation (oa, hatched bars) in different airway compartments. Data represent median values, interquartiles, and 10th and 90th percentiles of four to six animals. Statistical analysis: ${ }^{*} p<0.01$, Mann-Whitney rank sum test.

by the observation that levels of eosinophil peroxidase (EPO) in BAL fluid were already enhanced at $6 \mathrm{~h}$ after allergen challenge. ${ }^{40}$ Moreover, in the same model, we have recently observed, in contrast to the number of BAL eosinophils, that the activation state of the cells (measured as EPO release) is higher at $6 \mathrm{~h}$ after provocation than at $24 \mathrm{~h}$ after the challenge, while a significant correlation was found between the increased EPO release from the BAL cells and histamine $\mathrm{PC}_{100}$ values at $6 \mathrm{~h}$, but not at $24 \mathrm{~h}$, after allergen provocation (De Boer et al., unpublished results).

A third cause of possible dissociation between inflammatory cell numbers and AHR in asthmatics could be progressive airway remodeling, charac- 


\section{CD3-positive cells}
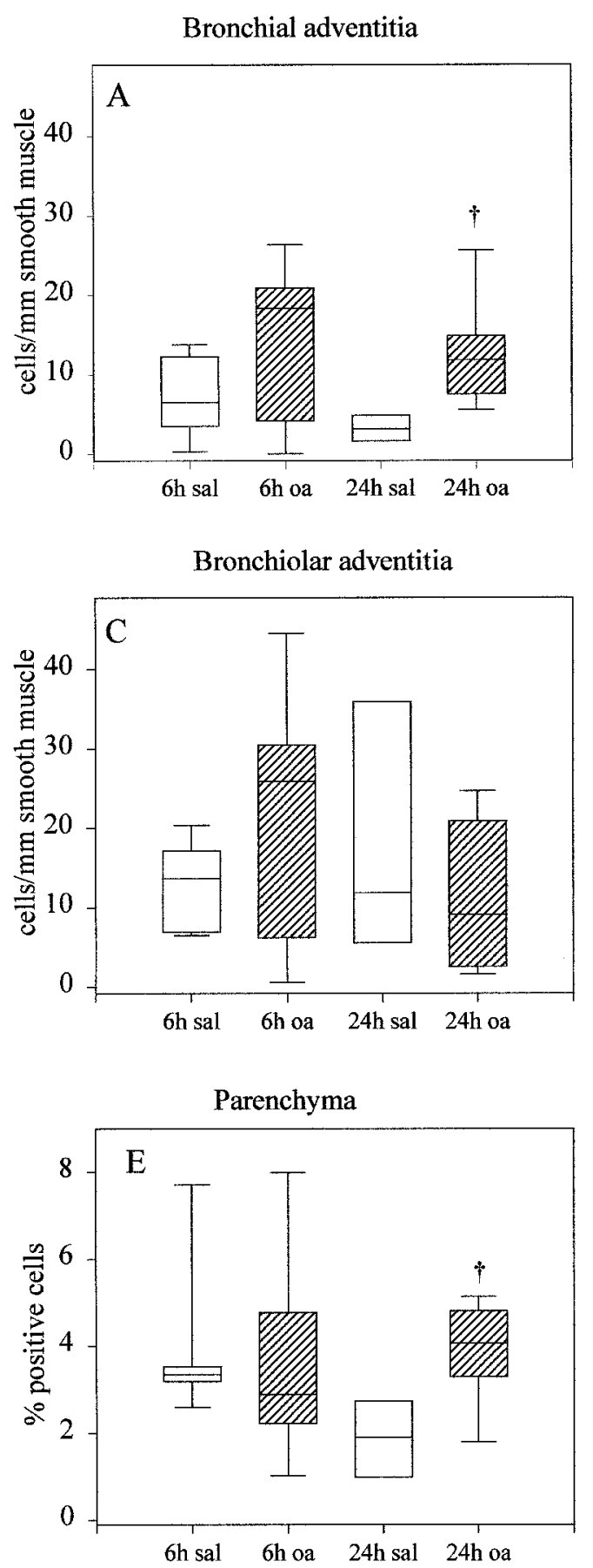

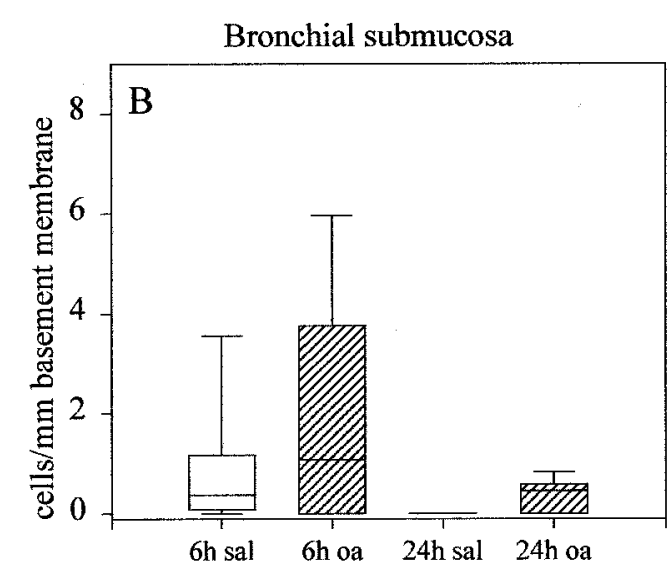

Bronchiolar submucosa

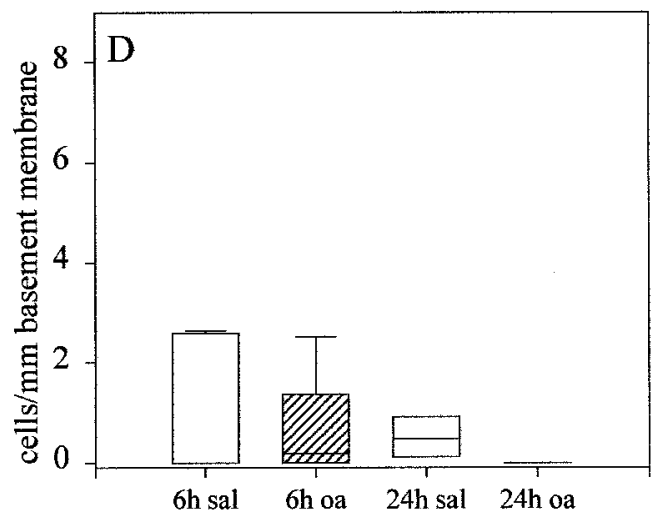

FIG. 5. Numbers of $\mathrm{CD}^{+}$cells at 6 and $24 \mathrm{~h}$ after saline control inhalation (sal, open bars) or ovalbumin inhalation (oa, hatched bars) in different airway compartments. Data represent median values, interquartiles, and 10th and 90th percentiles of four to six animals. Statistical analysis: $\dagger p<0.05$, Mann-Whitney rank sum test.

terized by thickening of the basement membrane, subepithelial fibrosis, and hypertrophy and hyperplasia of airway smooth muscle, as occurs in chronic asthma with persistent airway inflammation. ${ }^{41}$ In the presence of these morphological changes, the presence of particular inflammatory cells in the airways is not a prerequisite for (baseline) AHR.
Similar to the findings in the present study, the occurrence of preferential adventitial rather than submucosal eosinophilia after allergen challenge has been reported previously in guinea pigs. ${ }^{42,43}$ However, in the study of Frew et al. ${ }^{43}$ tissue eosinophilia was observed between 17 and $48 \mathrm{~h}$ after the challenge instead of after $6 \mathrm{~h}$ as observed in the present study. 
Lapa e Silva et $a l^{42}$ found no increase in submucosal eosinophil numbers at 2 and $24 \mathrm{~h}$ after challenge, while adventitial eosinophils were elevated at $24 \mathrm{~h}$ but not at $2 \mathrm{~h}$ after allergen challenge. Different sensitization and provocation procedures may account for the different kinetics of infiltration of inflammatory cells in these models compared with our model. Lapa e Silva et $a .^{42}$ used an additional booster for sensitization and challenged by the intraperitoneal route instead of the inhalational route. Frew et $a l .{ }^{43}$ sensitized guinea pigs by inhalation, challenged under protection of the $\mathrm{H}_{1}$ receptor antagonist mepyramine and measured airway resistance in a whole-body plethysmograph, while in our model measurements were performed under freely moving conditions, without antihistamine protection. Very importantly, we have previously demonstrated that mepyramine treatment may affect allergeninduced asthmatic reactions, AHR and infiltration of inflammatory cells. ${ }^{44}$

In lung tissue from patients with fatal asthma, as well as lung specimens from asthmatics obtained at surgery for lung cancer, adventitial eosinophilia has also been described. In lung specimens obtained from patients with asthma, Hamid et al. ${ }^{45}$ found greater numbers of eosinophils in the adventitia as compared with the submucosa of airways with an internal perimeter greater than $2 \mathrm{~mm}$; however, activated eosinophils seemed more numerous in the submucosa. In a recent study, Haley et al. ${ }^{46}$ reported a difference in eosinophil distribution between large and small airways in lung tissue from patients who died from status asthmaticus. As in our study, the eosinophilic infiltrate in the small airways was predominantly found in the adventitia. On the contrary, large airways predominantly showed submucosal eosinophilia, while both adventitial and submucosal accumulation was found in our study. However, both for the adventitial and the submucosal compartments, the eosinophil infiltration was not significantly different between large and small airways in our study. In line with these results, Carroll et al. ${ }^{15}$ also found no difference in eosinophil densities between large and small airways in the inner wall area between the basement membrane and the outer border of the smooth muscle in patients dying from asthma. Since studies performed on autopsy material of patients represent cellular infiltration in a state of chronic asthma, the relevance of the actual inflammatory cell counts in this tissue in the contribution to AHR is unknown.

Both human and guinea pig studies have indicated that various mechanisms may be involved in eosinophil-induced AHR. Although eosinophilic infiltration was mainly adventitial and epithelial damage was not investigated in this study, it is well known that eosinophilic granular cationic proteins may cause epithelial damage, thereby causing enhanced airway permeability and exposing the underlying sensory nerves, which may lead to enhanced cholinergic and excitatory non-adrenergic non-cholinergic reflex activities. ${ }^{47-49}$ Enhanced cholinergic reflex activity after allergen challenge may also develop from a dysfunction of autoinhibitory prejunctional muscarinic $\mathrm{M}_{2}$ receptors induced by eosinophil-derived MBP. ${ }^{50-52}$ In addition, it has recently been established that eosinophilic polycations may be involved in a deficiency of bronchodilating NO in the airways, presumably by inhibition of cellular uptake of L-arginine, the substrate for NO synthase..$^{53-57}$ Finally, it is known that eosinophil-derived mediators like LTC $_{4}$ and reactive oxygen species may cause swelling of the airway tissue by enhanced vascular permeability. $^{58}$ Since adventitial eosinophilia was most pronounced, it is tempting to speculate that uncoupling of the airway smooth muscle from the parenchyma caused by eosinophil-induced outer wall swelling, as proposed by Lambert et al., ${ }^{59}$ is an important determinant of the observed AHR.

In line with our results, several studies have demonstrated increased neutrophil numbers in BAL fluid from asthmatics and from guinea pigs after allergen challenge. $2,18,38,60$ Moreover, there are increasing indications that neutrophils may play a role in acute severe asthma. Thus, enhanced infiltration and/or activation of neutrophils has been demonstrated in fatal asthma of sudden onset, ${ }^{61}$ status asthmaticus, ${ }^{62}$ and during exacerbations of asthma. ${ }^{63}$ In addition, recent evidence from bronchial biopsies ${ }^{64}$ and induced sputum ${ }^{65}$ indicates that neutrophils may also be involved in severe persistent asthma.

The role of neutrophils in the development of allergen-induced AHR is presently unclear. Neutrophils have the capacity to generate enhanced levels of superoxide anion $\left(\mathrm{O}_{2}^{-}\right)$in patients with asthma, which correlates with the airway reactivity to methacholine in these patients. ${ }^{66}$ In the presence of high concentrations of inducible nitric oxide synthase (iNOS)-derived nitric oxide in the inflamed airways, $\mathrm{O}_{2}{ }^{-}$may cause formation of the highly cytotoxic oxidant peroxynitrite $\left(\mathrm{ONOO}^{-}\right)$, which has been found to induce AHR. ${ }^{67}$ Moreover, $\mathrm{ONOO}^{-}$was demonstrated to increase the release of MBP from eosinophils in tracheal preparations, ${ }^{67}$ while neutrophils may also enhance eosinophilic $\mathrm{LTC}_{4}$ production. ${ }^{68}$ In addition, neutrophils may enhance eosinophil recruitment and degranulation through secretion of IL-8. ${ }^{65,69,70}$

Elevated $\mathrm{CD}^{+}$cells were found only at $24 \mathrm{~h}$ after allergen provocation, both in the parenchyma and in the bronchial adventitia. In addition, the number of $\mathrm{CD}^{+}$cells in the parenchyma was correlated with AHR. The observed rise in $\mathrm{CD}^{+}$cells was not associated with a change in $\mathrm{CD}^{+}$cells. In the absence of a specific antibody directed against guinea pig $\mathrm{CD}^{+}$cells, the likely $\mathrm{CD}^{+}$character of these 
$\mathrm{CD}^{+} \mathrm{CD}^{-}$cells, as in humans, remains to be established. Elevated $\mathrm{CD}^{+} \mathrm{CD}^{-}$lymphocytes in guinea pig bronchus, but not parenchyma, were also observed by Frew et al. ${ }^{43}$ at 17 and $48 \mathrm{~h}$ after allergen. $\mathrm{CD}^{+}$ Th2-lymphocytes could contribute to AHR by activation of eosinophils by the production of IL $-5 .^{71}$

In conclusion, our findings indicate that, in addition to (sub-)mucosal inflammation, inflammation in the adventitia of both large and small airways could be importantly involved in the development of AHR in a guinea pig model of acute allergic asthma. Although investigations of the entire human airway circumference in relation to allergen-induced AHR are hampered by technical limitations, this finding may be of importance for asthmatic patients, and merits further investigation.

ACKNOWLEDGEMENTS. This work was supported by the Netherlands Asthma Foundation (grant 97.23) and the Jan Kornelis de Cock Foundation (grant 95.24). The authors wish to thank Dr H.M. Boezen for excellent statistical advice.

\section{References}

1. de Monchy JG, Kauffman HF, Venge P, Koeter GH, Jansen HM, Sluiter HJ, de Vries K. Bronchoalveolar eosinophilia during allergen-induced late asthmatic reactions. Am Rev Respir Dis 1985; 131: 373-376.

2. Metzger WJ, Zavala D, Richerson HB, Moseley P, Iwamota P, Monick M, Sjoerdsma K, Hunninghake GW. Local allergen challenge and bronchoalveolar lavage of allergic asthmatic lungs. Description of the model and local airway inflammation. Am Rev Respir Dis 1987; 135: 433-440.

3. Aalbers R, Kauffman HF, Vrugt B, Koeter GH, de Monchy JG. Allergeninduced recruitment of inflammatory cells in lavage 3 and $24 \mathrm{~h}$ after challenge in allergic asthmatic lungs. Chest 1993; 103: 1178-1184.

4. Beasley R, Roche WR, Roberts JA, Holgate ST. Cellular events in the bronchi in mild asthma and after bronchial provocation. Am Rev Respir Dis 1989; 139: 806-817.

5. Cockcroft DW, Ruffin RE, Dolovich J, Hargreave FE. Allergen-induced increase in non-allergic bronchial reactivity. Clin Allergy 1977; 7: 503-513.

6. Cartier A, Thomson NC, Frith PA, Roberts R, Hargreave FE. Allergeninduced increase in bronchial responsiveness to histamine: relationship to the late asthmatic response and change in airway caliber. $J$ Allergy Clin Immunol 1982; 70: 170-177.

7. Durham SR, Kay AB. Eosinophils, bronchial hyperreactivity and latephase asthmatic reactions. Clin Allergy 1985; 15: 411-418.

8. Aalbers R, Kauffman HF, Groen H, Koeter GH, de Monchy JG. The effect of nedocromil sodium on the early and late reaction and allergen-induced bronchial hyperresponsiveness. J Allergy Clin Immunol 1991; 87: 993-1001.

9. Crimi E, Spanevello A, Neri M, Ind PW, Rossi GA, Brusasco V. Dissociation between airway inflammation and airway hyperresponsiveness in allergic asthma. Am J Respir Crit Care Med 1998; 157: 4-9.

10. Brusasco V, Crimi E, Pellegrino R. Airway hyperresponsiveness in asthma: not just a matter of airway inflammation. Thorax 1998; 53: 992-998.

11. Haley KJ, Drazen JM. Inflammation and airway function in asthma: what you see is not necessarily what you get. Am J Respir Crit Care Med 1998; 157: $1-3$.

12. Dunnill MS, Massarella GR, Anderson JA. A comparison of the quantitative anatomy of the bronchi in normal subjects, in status asthmaticus, in chronic bronchitis and in emphysema. Thorax 1969; 24: 176-179.

13. Saetta M, Di-Stefano A, Rosina C, Thiene G, Fabbri LM. Quantitative structural analysis of peripheral airways and arteries in sudden fatal asthma. Am Rev Respir Dis 1991; 143: 138-143.

14. Synek M, Beasley R, Frew AJ, Goulding D, Holloway L, Lampe FC, Roche WR, Holgate ST. Cellular infiltration of the airways in asthma of varying severity. Am J Respir Crit Care Med 1996; 154: 224-230.

15. Carroll N, Cooke C, James A. The distribution of eosinophils and lymphocytes in the large and small airways of asthmatics. Eur Respir J 1997; 10: 292-300.

16. Brandtzaeg P, Jahnsen FL, Farstad IN. Immune functions and immunopathology of the mucosa of the upper respiratory pathways. Acta Otolaryngol Stockb 1996; 116: 149-159.

17. Dunnill MS. The pathology of asthma with special reference to changes in the bronchial mucosa. J Clin Patbol 1960; 13: 27-33.

18. Santing RE, Olymulder CG, Zaagsma J, Meurs H. Relationships among allergen-induced early and late phase airway obstructions, bronchial hyperreactivity, and inflammation in conscious, unrestrained guinea pigs. J Allergy Clin Immunol 1994; 93: 1021-1030.

19. Van Amsterdam RG, Brouwer F, Zaagsma J. Analysis of the betaadrenoceptor mediated inhibition of IgG1 and IgE dependent guinea-pig anaphylactic tracheal smooth muscle contraction. Agents Actions 1989; 26: $48-51$.

20. Santing RE, Meurs H, van der Mark TW, Remie R, Oosterom WC, Brouwer F, Zaagsma J. A novel method to assess airway function parameters in chronically instrumented, unrestrained guinea-pigs. Pulm Pharmacol 1992; 5: 265-272.

21. Erjefalt JS, Sundler F, Persson CG. Eosinophils, neutrophils, and venular gaps in the airway mucosa at epithelial removal-restitution. Am J Respir Crit Care Med 1996; 153: 1666-1674.

22. Tan BTG, Ekelaar F, Luirink J, Rimmelzaan G, Jonge-de AJR, Scheper RJ. Production of monoclonal antibodies defining guinea pig T-cell surface markers and a strain 13 Ia-like antigen: the value of immunohistological screening. Hybridoma 1985; 115-124.

23. Weibel ER. Stereological Methods Volume 2: Theoretical Foundations London: Academic Press, 1980:76-80.

24. Kirby JG, Hargreave FE, Gleich GJ, O'Byrne PM. Bronchoalveolar cell profiles of asthmatic and nonasthmatic subjects. Am Rev Respir Dis 1987; 136: 379-383.

25. Wardlaw AJ, Dunnette S, Gleich GJ, Collins JV, Kay AB. Eosinophils and mast cells in bronchoalveolar lavage in subjects with mild asthma. Relationship to bronchial hyperreactivity. Am Rev Respir Dis 1988; 137: 62-69.

26. Kelly C, Ward C, Stenton CS, Bird G, Hendrick DJ, Walters EH. Number and activity of inflammatory cells in bronchoalveolar lavage fluid in asthma and their relation to airway responsiveness. Thorax 1988; 43 684-692.

27. Brusasco V, Crimi E, Gianiorio P, Lantero S, Rossi GA. Allergen-induced increase in airway responsiveness and inflammation in mild asthma. $J$ Appl Physiol 1990; 69: 2209-2214.

28. Pin I, Radford S, Kolendowicz R, Jennings B, Denburg JA, Hargreave FE, Dolovich J. Airway inflammation in symptomatic and asymptomatic children with methacholine hyperresponsiveness. Eur Respir J 1993; 6 : 1249-1256.

29. Iredale MJ, Wanklyn SA, Phillips IP, Krausz T, Ind PW. Non-invasive assessment of bronchial inflammation in asthma: no correlation between eosinophilia of induced sputum and bronchial responsiveness to inhaled hypertonic saline. Clin Exp Allergy 1994; 24: 940-945.

30. Kidney JC, Wong AG, Efthimiadis A, Morris MM, Sears MR, Dolovich J, Hargreave FE. Elevated B cells in sputum of asthmatics. Close correlation with eosinophils. Am J Respir Crit Care Med 1996; 153: 540-544.

31. Pizzichini E, Pizzichini MM, Efthimiadis A, Evans S, Morris MM, Squillace D, Gleich GJ, Dolovich J, Hargreave FE. Indices of airway inflammation in induced sputum: reproducibility and validity of cell and fluid-phase measurements. Am J Respir Crit Care Med 1996; 154: 308-317.

32. Jeffery PK, Wardlaw AJ, Nelson FC, Collins JV, Kay AB. Bronchial biopsies in asthma. An ultrastructural, quantitative study and correlation with hyperreactivity. Am Rev Respir Dis 1989; 140: 1745-1753.

33. Djukanovic R, Wilson JW, Britten KM, Wilson SJ, Walls AF, Roche WR, Howarth PH, Holgate ST. Quantitation of mast cells and eosinophils in the bronchial mucosa of symptomatic atopic asthmatics and healthy control subjects using immunohistochemistry. Am Rev Respir Dis 1990; 142: $863-871$.

34. Bradley BL, Azzawi M, Jacobson M, Assoufi B, Collins JV, Irani AM, Schwartz LB, Durham SR, Jeffery PK, Kay AB. Eosinophils, T-lymphocytes, mast cells, neutrophils, and macrophages in bronchial biopsy specimens from atopic subjects with asthma: comparison with biopsy specimens from atopic subjects without asthma and normal control subjects and relationship to bronchial hyperresponsiveness. J Allergy Clin Immunol 1991; 88: 661-674.

35. Bentley AM, Menz G, Storz C, Robinson DS, Bradley B, Jeffery PK, Durham SR, Kay AB. Identification of T lymphocytes, macrophages, and activated eosinophils in the bronchial mucosa in intrinsic asthma. Relationship to symptoms and bronchial responsiveness. Am Rev Respir Dis 1992; 146: 500-506.

36. Ollerenshaw SL, Woolcock AJ. Characteristics of the inflammation in biopsies from large airways of subjects with asthma and subjects with chronic airflow limitation. Am Rev Respir Dis 1992; 145: 922-927.

37. Woolley KL, Adelroth E, Woolley MJ, Ellis R, Jordana M, O'Byrne PM. Granulocyte-macrophage colony-stimulating factor, eosinophils and eosinophil cationic protein in subjects with and without mild, stable, atopic asthma. Eur Respir J 1994; 7: 1576-1584.

38. Boichot E, Lagente V, Carre C, Waltmann P, Mencia Huerta JM, Braquet P. Bronchial hyperresponsiveness and cellular infiltration in the lung of guinea-pigs sensitized and challenged by aerosol. Clin Exp Allergy 1991; 21: $67-76$.

39. Aalbers R, de Monchy JG, Kauffman HF, Smith M, Hoekstra Y, Vrugt B, Timens W. Dynamics of eosinophil infiltration in the bronchial mucosa before and after the late asthmatic reaction. Eur Respir J 1993; 6 : $840-847$.

40. Santing RE, Hoekstra Y, Pasman Y, Zaagsma J, Meurs H. The importance of eosinophil activation for the development of allergen-induced bronchial hyperreactivity in conscious, unrestrained guinea-pigs. Clin Exp Allergy 1994; 24: 1157-1163. 
41. James AL, Pare PD, Hogg JC. The mechanics of airway narrowing in asthma. Am Rev Respir Dis 1989; 139: 242-246.

42. Lapa e Silva JR, Bachelet CM, Pretolani M, Baker D, Scheper RJ, Vargaftig BB. Immunopathologic alterations in the bronchi of immunized guinea pigs. Am J Respir Cell Mol Biol 1993; 9: 44-53.

43. Frew AJ, Moqbel R, Azzawi M, Hartnell A, Barkans J, Jeffery PK, Kay AB, Scheper RJ, Varley J, Church MK, et al. T lymphocytes and eosinophils in allergen-induced late-phase asthmatic reactions in the guinea pig. $\mathrm{Am}$ Rev Respir Dis 1990; 141: 407-413.

44. Santing RE, Schraa EO, Wachters A, Olymulder CG, Zaagsma J, Meurs H Role of histamine in allergen-induced asthmatic reactions, bronchial hyperreactivity and inflammation in unrestrained guinea pigs. Eur $J$ Pharmacol 1994; 254: 49-57.

45. Hamid Q, Song Y, Kotsimbos TC, Minshall E, Bai TR, Hegele RG, Hogg JC Inflammation of small airways in asthma. J Allergy Clin Immunol 1997; 100: $44-51$.

46. Haley KJ, Sunday ME, Wiggs BR, Kozakewich HP, Reilly JJ, Mentzer SJ, Sugarbaker DJ, Doerschuk CM, Drazen JM. Inflammatory cell distribution within and along asthmatic airways. Am J Respir Crit Care Med 1998; 158: 565-572.

47. Gleich GJ, Flavahan NA, Fujisawa T, Vanhoutte PM. The eosinophil as a mediator of damage to respiratory epithelium: a model for bronchial hyperreactivity. J Allergy Clin Immunol 1988; 81: 776-781.

48. Santing RE, Pasman Y, Olymulder CG, Roffel AF, Meurs H, Zaagsma J Contribution of a cholinergic reflex mechanism to allergen-induced bronchial hyperreactivity in permanently instrumented, unrestrained guinea-pigs. Br J Pharmacol 1995; 114: 414-418.

49. Schuiling M, Zuidhof AB, Zaagsma J, Meurs H. Role of tachykinin NK1 and NK2 receptors in allergen-induced early and late asthmatic reactions, airway hyperresponsiveness, and airway inflammation in conscious, unrestrained guinea pigs. Clin Exp Allergy 1999; 29 (suppl 2): 48-52.

50. Minette PA, Lammers JW, Dixon CM, McCusker MT, Barnes PJ. A muscarinic agonist inhibits reflex bronchoconstriction in normal but not in asthmatic subjects. J Appl Pbysiol 1989; 67: 2461-2465.

51. Jacoby DB, Gleich GJ, Fryer AD. Human eosinophil major basic protein is an endogenous allosteric antagonist at the inhibitory muscarinic M2 receptor. J Clin Invest 1993; 91: 1314-1318.

52. Ten Berge RE, Santing RE, Hamstra JJ, Roffel AF Zaagsma J. Dysfunction of muscarinic M2 receptors after the early allergic reaction: possible contribution to bronchial hyperresponsiveness in allergic guinea-pigs. $\mathrm{Br}$ J Pharmacol 1995; 114: 881-887.

53. De Boer J, Meurs H, Coers W, Koopal M, Bottone AE, Visser AC, Timens W, Zaagsma J. Deficiency of nitric oxide in allergen-induced airway hyperreactivity to contractile agonists after the early asthmatic reaction: an ex vivo study. Br J Pharmacol 1996; 119: 1109-1116.

54. De Boer J, Duyvendak M, Schuurman FE, Pouw FM, Zaagsma J, Meurs H. Role of L-arginine in the deficiency of nitric oxide and airway hyperreactivity after the allergen-induced early asthmatic reaction in guinea-pigs. Br J Pharmacol 1999; 128: 1114-1120.

55. Ricciardolo FL, Geppetti P, Mistretta A, Nadel JA, Sapienza MA, Bellofiore S, Di Maria GU. Randomised double-blind placebo-controlled study of the effect of inhibition of nitric oxide synthesis in bradykinin-induced asthma. Lancet 1996; 348: 374-377.

56. Meurs H, Schuurman FE, Duyvendak M, Zaagsma J. Deficiency of nitric oxide in polycation-induced airway hyperreactivity. $\mathrm{Br} J$ Pharmacol 1999; 126: 559-562.
57. Hammermann R, Hirschmann J, Hey C, Mossner J, Folkerts G, Nijkamp FP, Wessler I, Racke K. Cationic proteins inhibit $\mathrm{L}$-arginine uptake in rat alveolar macrophages and tracheal epithelial cells. Implications for nitric oxide synthesis. Am J Respir Cell Mol Biol 1999; 21: 155-162.

58. Chung KF. Leukotriene receptor antagonists and biosynthesis inhibitors potential breakthrough in asthma therapy. Eur Respir J 1995; 8 1203-1213.

59. Lambert RK, Pare PD. Lung parenchymal shear modulus, airway wall remodeling, and bronchial hyperresponsiveness. J Appl Physiol 1997; 83: $140-147$.

60. Underwood S, Foster M, Raeburn D, Bottoms S, Karlsson JA. Time-course of antigen-induced airway inflammation in the guinea-pig and its relationship to airway hyperresponsiveness. Eur Respir J 1995; 8: 2104-2113.

61. Sur S, Crotty TB, Kephart GM, Hyma BA, Colby TV, Reed CE, Hunt LW, Gleich GJ. Sudden-onset fatal asthma. A distinct entity with few eosinophils and relatively more neutrophils in the airway submucosa? Am Rev Respir Dis 1993; 148: 713-719.

62. Lamblin C, Gosset P, Tillie L, I, Saulnier F, Marquette CH, Wallaert B, Tonnel AB. Bronchial neutrophilia in patients with noninfectious status asthmaticus. Am J Respir Crit Care Med 1998; 157: 394-402.

63. Fahy JV, Kim KW, Liu J, Boushey HA. Prominent neutrophilic inflammation in sputum from subjects with asthma exacerbation. J Allergy Clin Immunol 1995; 95: 843-852.

64. Wenzel SE, Szefler SJ, Leung DY, Sloan SI, Rex MD, Martin RJ. Bronchoscopic evaluation of severe asthma. Persistent inflammation associated with high dose glucocorticoids. Am J Respir Crit Care Med 1997; 156: 737-743

65. Jatakanon A, Uasuf C, Maziak W, Lim S, Chung KF, Barnes PJ. Neutrophilic inflammation in severe persistent asthma. Am J Respir Crit Care Med 1999; 160: 1532-1539.

66. Meltzer S, Goldberg B, Lad P, Easton J. Superoxide generation and its modulation by adenosine in the neutrophils of subjects with asthma. $J$ Allergy Clin Immunol 1989; 83: 960-966.

67. Sadeghi Hashijin G, Folkerts G, Henricks PA, Verheyen AK, van der Linde HJ, Van Ark I, Coene A, Nijkamp FP. Peroxynitrite induces airway hyperresponsiveness in guinea pigs in vitro and in vivo. Am J Respir Crit Care Med 1996; 153: 1697-1701.

68. Kloprogge E, de-Leeuw AJ, De-Monchy JG, Kauffman HF. Cellular communication in leukotriene $\mathrm{C} 4$ production between eosinophils and neutrophils. Int Arch Allergy Appl Immunol 1989; 90: 20-23.

69. Erger RA, Casale TB. Interleukin-8 is a potent mediator of eosinophil chemotaxis through endothelium and epithelium. Am J Physiol 1995; 268: L117-L122.

70. Shute JK, Vrugt B, Lindley IJ, Holgate ST, Bron A, Aalbers R, Djukanovic R. Free and complexed interleukin-8 in blood and bronchial mucosa in asthma. Am J Respir Crit Care Med 1997; 155: 1877-1883.

71. Corrigan CJ, Hamid Q, North J, Barkans J, Moqbel R, Durham S, Gemou EV, Kay AB. Peripheral blood CD4 but not CD8 T-lymphocytes in patients with exacerbation of asthma transcribe and translate messenger RNA encoding cytokines which prolong eosinophil survival in the context of a Th2-type pattern: effect of glucocorticoid therapy. Am J Respir Cell Mol Biol 1995; 12: 567-578.

Received 29 March 2001; accepted 17 April 2001 


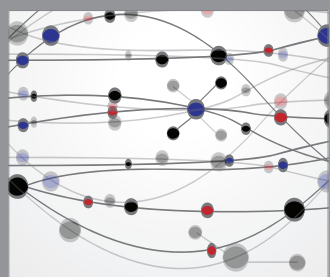

The Scientific World Journal
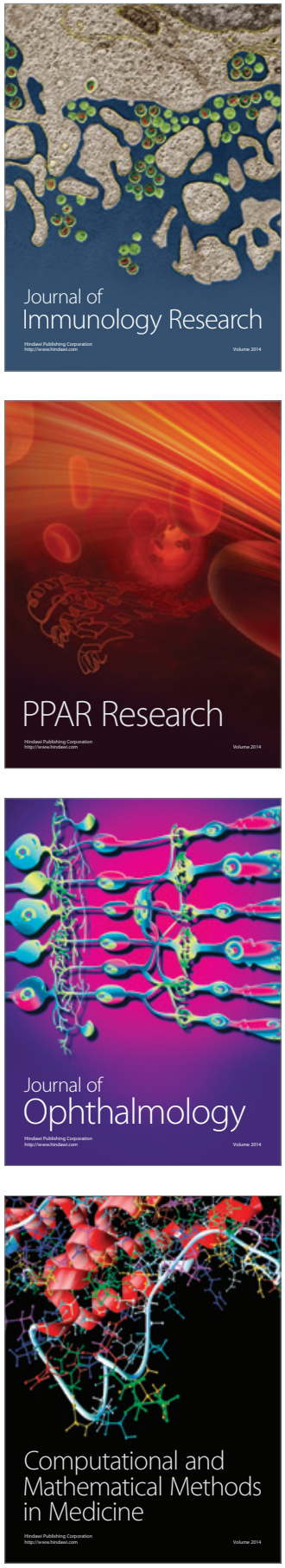

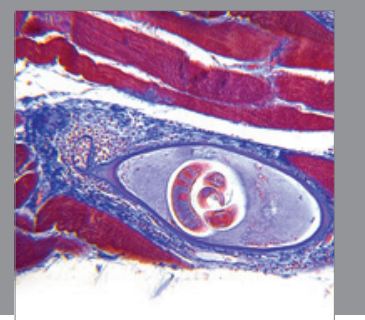

Gastroenterology

Research and Practice
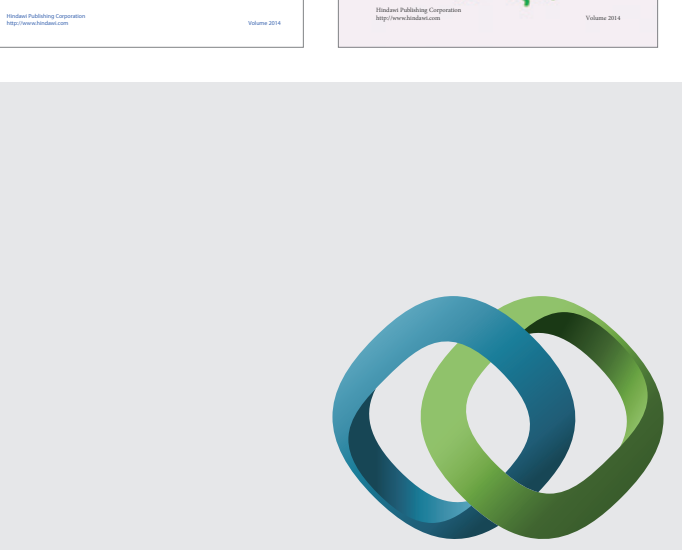

\section{Hindawi}

Submit your manuscripts at

http://www.hindawi.com
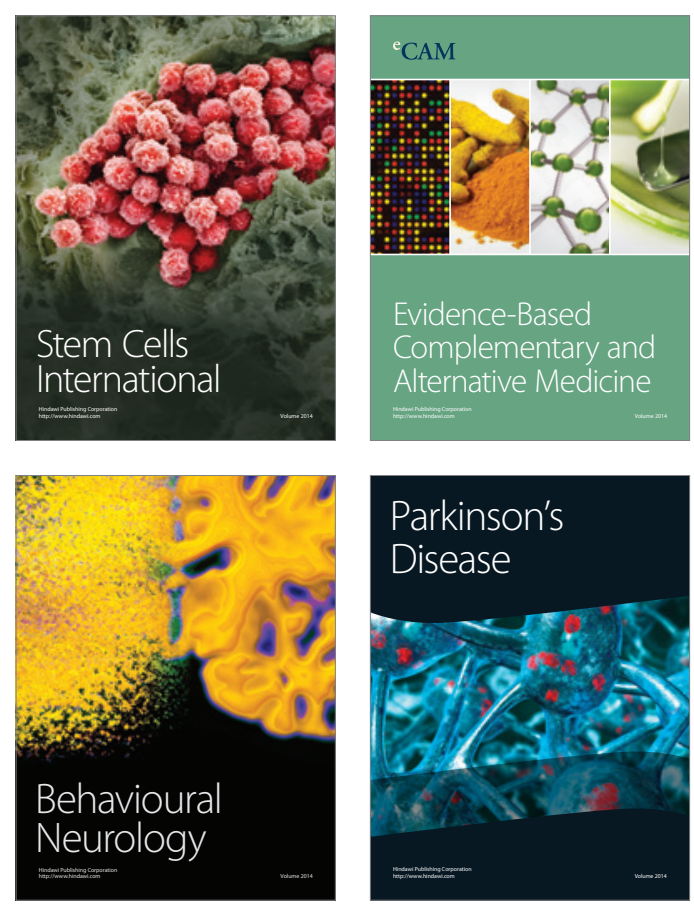

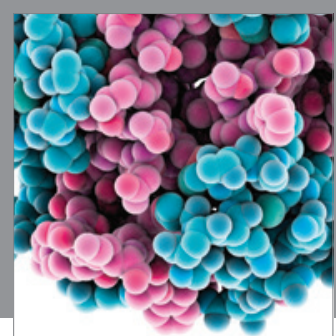

Journal of
Diabetes Research

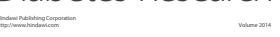

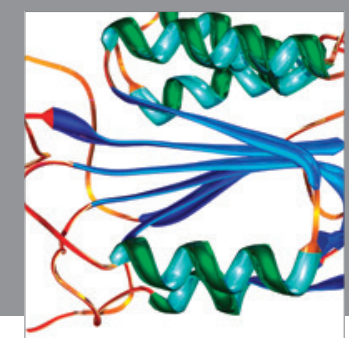

Disease Markers
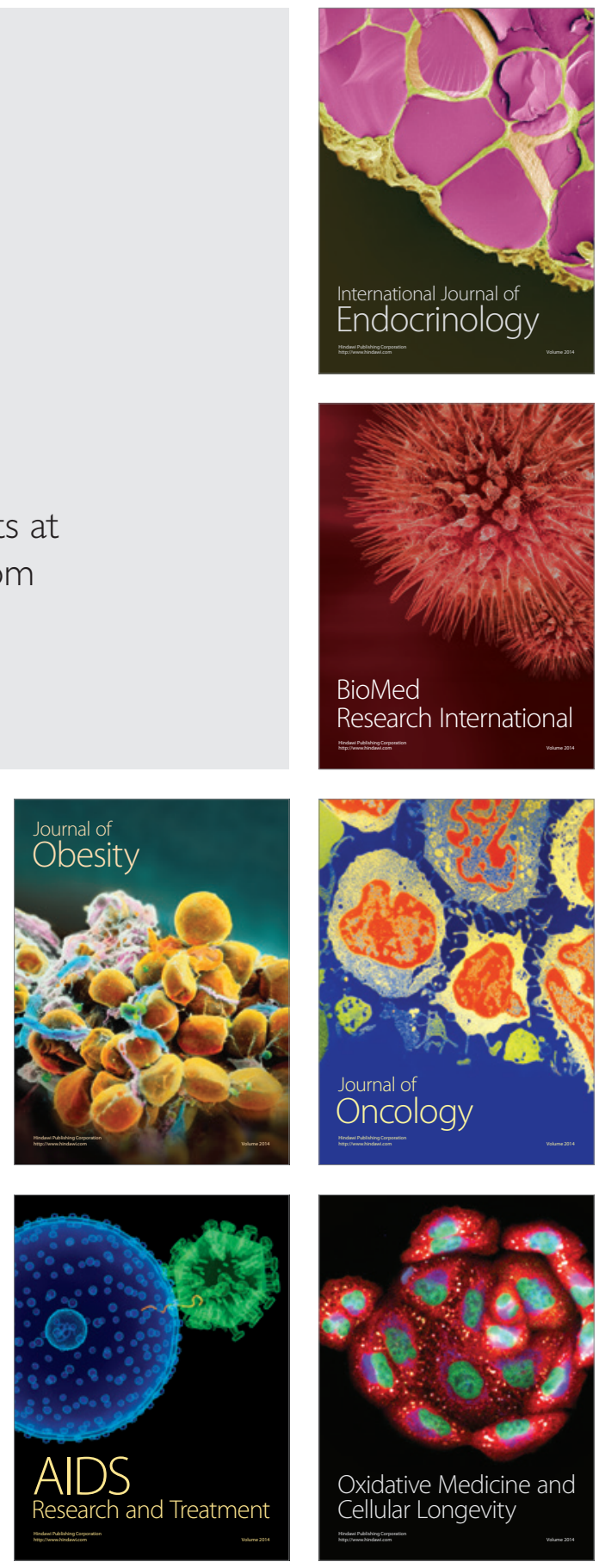